Institute for Research on Poverty

Discussion Paper no. 1138-97

\title{
Earnings of Black and White Youth and Their Relation to Poverty
}

\author{
Philip M. Gleason \\ Mathematica Policy Research \\ E-mail address: pgleason@mathematica-mpr.com \\ Glen G. Cain \\ Department of Economics \\ University of Wisconsin-Madison
}

August 1997

Much of this research was carried out while we were research fellows of the American Statistical Association/National Science Foundation at the U.S. Bureau of the Census. We are grateful for assistance from Robert Fay and David McMillen, and for research support from the Institute for Research on Poverty and the La Follette Institute of Public Affairs at the University of Wisconsin-Madison.

IRP publications (discussion papers, special reports, and the newsletter Focus) are now available electronically. The IRP Web Site can be accessed at the following address: http://www.ssc.wisc.edu/irp/ 


\begin{abstract}
This paper examines the relation between youth employment and poverty for black and white families. An increase in the employment proportions of black men ages 16-19, which have lagged far behind their white counterparts, would reduce poverty among blacks to a moderate but meaningful degree. We provide evidence of a small positive feedback relation between black youth employment and family incomes that would magnify gains in both variables if either variable were increased. We also provide evidence that improvements in labor market conditions that affect youth employment, in the educational attainments of black youth, and in other policy-related variables would raise both youth employment and their family incomes.
\end{abstract}




\section{Earnings of Black and White Youth and Their Relation to Poverty}

\section{PURPOSES AND MOTIVATION}

Economic analysis of the labor supply of young people who live with their parents traditionally includes attention to the effect of parental income or wealth on the youth's employment and earnings. In this paper we examine a particular aspect of the reverse relation: the effect that work by young men ages 16-19 has on their family's income and poverty status. To state the topic in this way signals that the relation between youth employment and family income is reciprocal. Identifying causality is beyond our reach, but we can quantify the association of these two economic outcomes for black and white families with a rich data source, the Survey of Income and Program Participation (SIPP).

The decline over time in the employment of black youth relative to white youth and the disturbing prospect of this trend for the future economic status of adult blacks are familiar issues. This paper deals instead with the contemporaneous influence of youth employment on family income and on the black-white difference in the incidence of poverty. We show that low employment by black youth and family poverty combine to create a depressing economic condition for a sizable minority of black families. These statistics on racial differences in youth employment and the incidence of poverty, along with finding an unexpected positive relation between the income of parents and the employment of their teenage children, motivate our study. We discuss each of these points in turn.

\section{The Time Trends of Youth Employment}

Table 1 shows the time trends from 1955 to 1995 in the ratios of civilian youth employment to the civilian youth population, E/P, for male and female, whites and blacks, in the age groups 16-19 and 
TABLE 1

Employment-to-Population Ratios (E/P) for Youth Ages 16-19 and 20-24, by Race and Gender, 1955-1995

\begin{tabular}{|c|c|c|c|c|c|c|c|c|}
\hline \multirow[b]{3}{*}{ Year } & \multicolumn{4}{|c|}{ MEN } & \multicolumn{4}{|c|}{ WOMEN } \\
\hline & \multicolumn{2}{|c|}{$16-19$} & \multicolumn{2}{|c|}{$20-24$} & \multicolumn{2}{|c|}{$16-19$} & \multicolumn{2}{|c|}{$20-24$} \\
\hline & White & Black & White & Black & White & Black & White & Black \\
\hline 1955 & .520 & .526 & .804 & .784 & .370 & .262 & .435 & .406 \\
\hline 1956 & .541 & .521 & .823 & .781 & .389 & .278 & .441 & .384 \\
\hline 1957 & .524 & .474 & .805 & .788 & .382 & .266 & .434 & .411 \\
\hline 1958 & .476 & .419 & .766 & .714 & .350 & .229 & .427 & .392 \\
\hline 1959 & .481 & .414 & .808 & .759 & .348 & .205 & .414 & .416 \\
\hline 1960 & .481 & .438 & .805 & .784 & .351 & .247 & .424 & .413 \\
\hline 1961 & .459 & .411 & .788 & .756 & .346 & .232 & .430 & .382 \\
\hline 1962 & .464 & .419 & .796 & .763 & .348 & .231 & .435 & .398 \\
\hline 1963 & .447 & .374 & .791 & .749 & .329 & .213 & .438 & .401 \\
\hline 1964 & .450 & .377 & .793 & .781 & .322 & .218 & .454 & .436 \\
\hline 1965 & .471 & .394 & .802 & .816 & .337 & .201 & .461 & .476 \\
\hline 1966 & .501 & .406 & .810 & .829 & .375 & .230 & .483 & .476 \\
\hline 1967 & .502 & .389 & .805 & .803 & .377 & .248 & .499 & .473 \\
\hline 1968 & .503 & .387 & .786 & .780 & .378 & .248 & .508 & .512 \\
\hline 1969 & .511 & .390 & .787 & .773 & .395 & .251 & .533 & .516 \\
\hline 1970 & .496 & .355 & .768 & .729 & .395 & .223 & .537 & .490 \\
\hline 1971 & .492 & .318 & .754 & .682 & .386 & .202 & .531 & .464 \\
\hline 1972 & .515 & .316 & .771 & .704 & .413 & .192 & .546 & .469 \\
\hline 1973 & .543 & .328 & .802 & .726 & .436 & .220 & .574 & .474 \\
\hline 1974 & .544 & .314 & .798 & .699 & .443 & .209 & .587 & .476 \\
\hline 1975 & .506 & .263 & .743 & .594 & .425 & .202 & .581 & .425 \\
\hline 1976 & .515 & .258 & .769 & .613 & .442 & .192 & .594 & .441 \\
\hline 1977 & .544 & .264 & .787 & .610 & .459 & .185 & .615 & .443 \\
\hline 1978 & .563 & .285 & .806 & .622 & .485 & .221 & .636 & .486 \\
\hline 1979 & .557 & .287 & .811 & .655 & .494 & .224 & .650 & .477 \\
\hline 1980 & .534 & .270 & .775 & .609 & .479 & .210 & .646 & .462 \\
\hline 1981 & .513 & .246 & .770 & .583 & .462 & .197 & .650 & .449 \\
\hline 1982 & .470 & .203 & .739 & .539 & .446 & .177 & .639 & .423 \\
\hline 1983 & .474 & .204 & .743 & .545 & .445 & .170 & .647 & .403 \\
\hline 1984 & .491 & .239 & .780 & .580 & .470 & .201 & .661 & .451 \\
\hline 1985 & .499 & .263 & .780 & .604 & .471 & .231 & .675 & .465 \\
\hline 1986 & .496 & .265 & .792 & .613 & .479 & .238 & .681 & .487 \\
\hline 1987 & .499 & .285 & .796 & .621 & .490 & .258 & .693 & .493 \\
\hline 1988 & .517 & .290 & .801 & .639 & .502 & .258 & .698 & .507 \\
\hline 1989 & .526 & .304 & .789 & .668 & .505 & .271 & 679 & .528 \\
\hline 1990 & .510 & .276 & .796 & .612 & .484 & .257 & .687 & .501 \\
\hline 1991 & .472 & .237 & .766 & .595 & .460 & .215 & 669 & .478 \\
\hline 1992 & .463 & .236 & .763 & .569 & .443 & .221 & 677 & .467 \\
\hline 1993 & .466 & .236 & .772 & .571 & .458 & .216 & .680 & .496 \\
\hline 1994 & .483 & .254 & .780 & .596 & .475 & .245 & .680 & .518 \\
\hline 1995 & .494 & .252 & .784 & .615 & .481 & .261 & .670 & .524 \\
\hline
\end{tabular}

Sources: U.S. Department of Labor (1989, Tables 3, 15, and 16); and Employment and Earnings, January issues, 1990-1996. 
20-24. ${ }^{1}$ (See also Figure 1.) In 1995 the E/Ps for white men ages 16-19 and 20-24 (Table 1) were .49 and .78 , respectively, and were only .25 and .62 for black men of those age groups. Note that these lower levels of employment for blacks exist despite their disadvantages in lower parental incomes, which imply a greater need for earnings, and in their slightly lower enrollments in advanced schooling, which is the main alternative activity of young men to employment. The current racial gap in employment is the result of a sharp divergence that began forty years ago in the time trends for the two groups: a pronounced declining trend for black young men and a fairly flat trend for whites. In 1955 the E/Ps of blacks were roughly the same as those for whites: about .52 for both white and black teenage males, and .80 and .78 for white and black men ages 20-24.

A similar growing gap between the E/Ps of white and black young women also occurred during this period, although the direction of the women's trend lines differ from those of men. The E/Ps for white women ages 16-19 rose from .37 in 1955 to .48 in 1995, while the E/Ps of black women of this age remained at .26 for these two end-point years. The 11 percentage-point white-to-black gap grew to a 22 percentage-point gap in this age group. The E/Ps for white women ages 20-24 rose from .44 in 1955 to .67 in 1995; for black women ages 20-24, the rise was from .41 to .52: the 3 percentage-point gap rose to 15 percentage points.

Several brief comments about the economic and social forces behind these trends are useful. Consider the rise in E/Ps for young white women and the nearly steady levels of E/Ps for young white men. Operating to decrease the E/Ps, over the 1955-95 period as a whole, were the growth in parents' incomes and the associated rise in the proportion of young people who extended their years of education. Operating to increase the E/Ps was the rise in the market demand for youth labor, which was reflected in rising real wages. (The increase in real family income was almost entirely attributable to the increase in

\footnotetext{
${ }^{1}$ The E/P is similar to the more commonly used labor force participation rate, which is defined with the civilian population in the denominator and the sum of the employed plus the unemployed in the numerator. We use $\mathrm{E} / \mathrm{P}$ because it measures the fraction of the youth population that has been successful in obtaining a job.
} 
FIGURE 1

Employment-to-Population Ratios 16-19-year-olds, 1955-1995

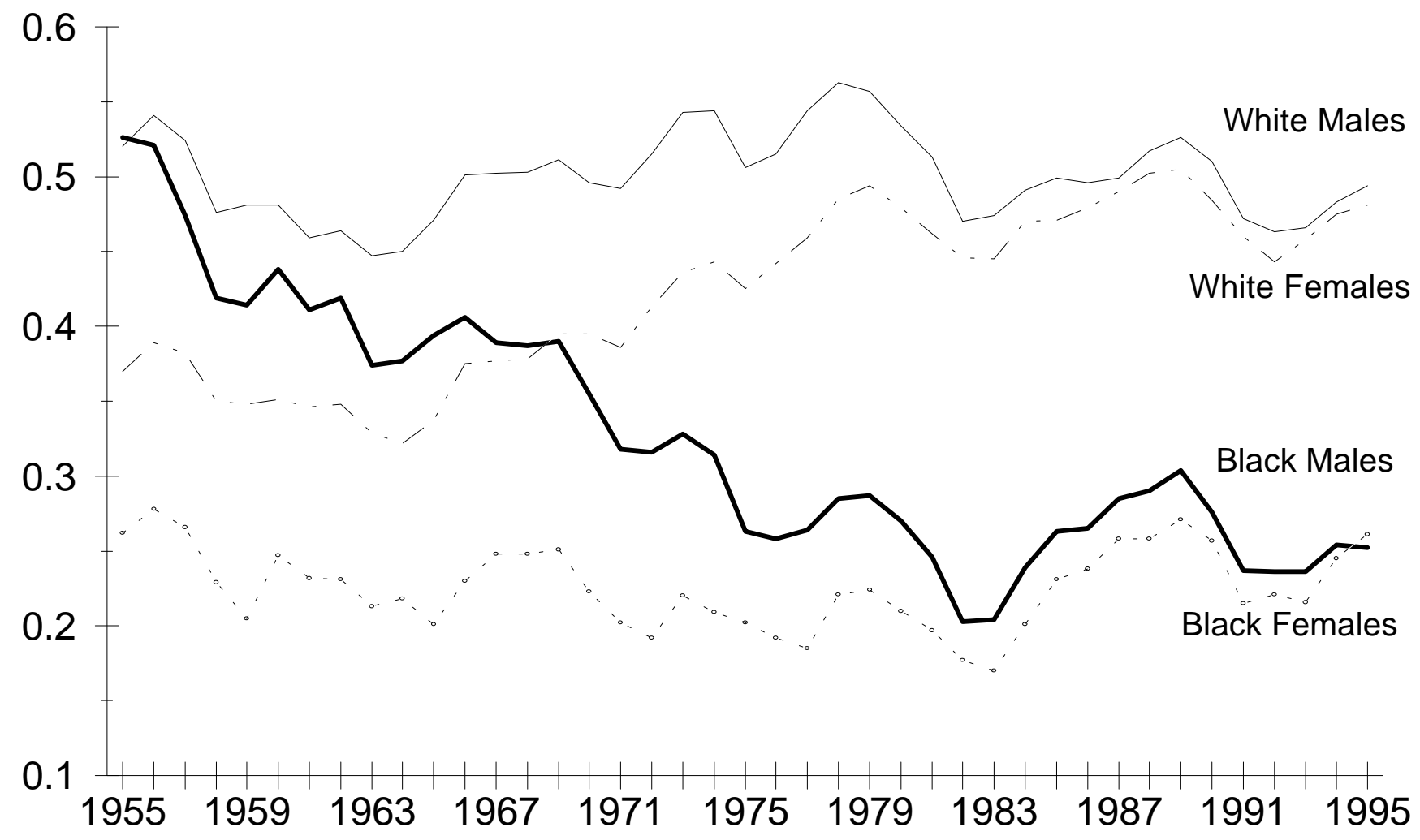


real wages for most of the population.) The increase in demand for young people's labor was often in the form of the growth in part-time jobs in the service industries, such as retail trade and fast-food restaurants, which accommodated combining employment with schooling.

For young white men the demand increase appears to have just offset the anti-work (and pro-education) changes on the supply side. For women, white and black, the increase in market demand may have been greater than it was for men. Women's employment opportunities have been improved relative to men's by technological changes that have substituted mental skills for physical skills and by the increases in the demand for services relative to goods from manufacturing and agriculture. Also, lower fertility and delayed age of marriages increased the employment of women, although these relations surely reflect mutual causality; specifically, the effects that rising wages and employment opportunities for women had on delaying their age of marriage and reducing their desired fertility rate.

The forces affecting the employment status of black youth are similar but more complicated. In the early part of the forty-year period under analysis a substantial part of the black youth population lived in the rural South, where E/Ps are relatively high, especially for men. In this setting, poverty and limited schooling opportunities were pervasive, and underemployment was high (although unemployment was low). The migration of blacks to urban areas, especially to the North, can explain some of the decline in E/Ps during, say, the ten years from 1955 to $1965 .^{2}$ However, by 1965 most of the black population lived in urban settings, whether in the North or South, and the declines in the E/Ps of black youth continued in the post-1965 period. Another factor that contributed slightly to the widening racial gap in E/Ps during the first half of the forty-year period is the gain in educational attainments of black youth, which was more rapid than the educational gain of whites. The relative schooling gains of blacks abated during the

\footnotetext{
${ }^{2}$ The trend from 1940 to 1980 in the proportion of black youth ages 16-24 living in rural areas is as follows: 55 percent in 1940, 31 percent in 1960, and 15 percent in 1980. Almost all black rural residents were in the South. The trend for white youth ages 16-24 is: 43 percent in 1940, 29 percent in 1960, and 25 percent in 1980 (U.S. Bureau of the Census 1943, Table 7; 1964, Table 155; 1983, Table 41).
} 
1975-95 period, however, so the continued relative decline in black youth E/Ps cannot be explained by schooling trends. ${ }^{3}$ Again, some reverse causation may be in effect, because poorer employment opportunities for black youth compared to whites may have been causal to the decisions of black youth to stay in school longer.

Fertility rates of young black women are higher than those of whites, so this barrier to women's employment is one explanation for the lower level of the black E/Ps. The role of fertility in explaining the trend differences is less clear; white women ages 15-19 and 20-24 and black women ages 20-24 showed sharp declines in fertility over the forty-year period, while the trend for black women ages 15-19 was nearly constant. ${ }^{4}$ The increase in the proportion of the low-income population participating in welfare programs, particularly Aid to Families with Dependent Children (AFDC), is another femalespecific source for declining employment, particularly among young black women. ${ }^{5}$ As we discuss below, however, this source of a disincentive to work should not be important among black men, and the decline in E/Ps is much sharper for young black men than for young black women.

The foregoing discussion has mainly mentioned supply-side factors; that is, factors that affect a person's offer of labor to the market. The demand side — the job offers made by employers—-has also received much attention. The hypothesis of a decline in the market demand for the labor of black youth

${ }^{3}$ The black-to-white ratios of school enrollment proportions for 16-17-year-olds are: .90 (=.72/.80) in 1947, $.94(=.85 / .90)$ in $1957, .94(=.85 / .89)$ in 1967 , and $1.03(=.91 / .88)$ in 1977. The black-to-white ratios of school enrollment for 18-19-year-olds increased from $.84(=.407 / .484)$ in 1967 to $1.06(=.483 / .455)$ in 1977 . It should be noted that if we measure success in high school by the proportion of 18-24-year-olds who have graduated, then the racial gap in this measure has been more prolonged. The black-to-white ratios of graduates were $.72(=.56 / .78)$ in 1967 and .93 (=.77/.83) in 1994 (U.S. Bureau of the Census 1996, p. xii; 1992, pp. A6, A12).

${ }^{4}$ In 1959 the numbers of children ever born per 1000 women (married and unmarried) ages 15-19 and 20-24 were 103 and 1,025, respectively, for whites; 179 and 1,426 for blacks (officially nonwhites). In 1992 the corresponding numbers of children ever born were 73 for white women ages 15-19; 455 for white women ages 20-24; 185 for black women ages 15-19; and 1,011 for black women ages 20-24 (U.S. Bureau of the Census 1961, Table 1; U.S. Bureau of the Census, 1993b, Table 1).

${ }^{5}$ The U.S. Bureau of the Census reported in 1995 that 25 percent of black mothers and 7 percent of white mothers between the ages of 15 and 44 received payments from AFDC (U.S. Bureau of the Census 1995b). 
is, however, difficult to accept in the face of the overall rise in real wages during the 1955-95 period. ${ }^{6}$

Nevertheless, the argument that the demand for black youth fell relative to whites has received considerable support. ${ }^{7}$

There is much more that could be said about the trends in youth employment, but our main subject is the relation between youth employment and family poverty, and to this end we will focus on males from ages 16 to 19 . Males in this younger group, unlike the 20-24-year-olds, mostly live with their parents, and the relation between their parents' income and their employment status is directly observed in the survey data we use in this study. Also, the 16-19-year-old men are less likely to be married and raising children than women of this age. In 1990, for example, among white women who were 15 to 19 years old, 11 percent were (or had been) married, and among all white women of this age there were 113 children ever born per 1000 women. The corresponding statistics for black women of that age are 3 percent ever married and 210 children ever born per 1000 women. Also, in 1990 among 18-19-year-olds, 10 percent of women and only 3 percent of men were currently married (U.S. Bureau of the Census 1992, pp. 45,71$)$.

\section{Trends in Family Poverty}

Table 2 shows family poverty rates (the proportion of families whose annual incomes fall below the official "poverty line") averaged over five-year periods from 1959 to 1995 (except for the two-year period 1959-60). During this period the average annual poverty rate was 34 percent among black families and 10 percent among white families, with a declining trend over the first half of the period and

${ }^{6}$ See Welch (1990) for a strong, although we believe overstated, case for explaining the decline in the E/Ps of black youth to be the result of a large decline in the supply of labor of black youth, given the rise in the market demand for the labor of black youth.

${ }^{7} \mathrm{~A}$ huge research literature has grown around the issue of declining job opportunities for black youth, primarily as a consequence of the exodus of businesses from inner cities to suburbs and the movement of businesses from areas with relatively large black populations (the "rust belt") to areas with relatively small black populations (the "sun belt"). See Moss and Tilly (1991) for a review of this literature. 
TABLE 2

Average Employment-to-Population Ratios for 16-19-Year-Old Men and Family Poverty Rates: Whites and Blacks, 1959-1995

\begin{tabular}{|c|c|c|c|c|}
\hline \multirow[b]{2}{*}{ Year } & \multicolumn{2}{|c|}{$\begin{array}{c}\text { Employment-to-Population } \\
\text { Ratio, Men 16-19 }\end{array}$} & \multicolumn{2}{|c|}{$\begin{array}{c}\text { Family } \\
\text { Poverty Rate }\end{array}$} \\
\hline & Whites & Blacks & Whites & Blacks \\
\hline $1959-60$ & .475 & .426 & 15.0 & 49.8 \\
\hline $1961-65$ & .451 & .395 & 13.0 & 45.0 \\
\hline $1966-70$ & .487 & .385 & 8.4 & 30.2 \\
\hline $1971-75$ & .492 & .308 & 7.2 & 28.0 \\
\hline $1976-80$ & .506 & .273 & 7.2 & 28.1 \\
\hline $1981-85$ & .452 & .231 & 9.3 & 31.1 \\
\hline 1986-90 & .475 & .284 & 8.1 & 28.5 \\
\hline 1991-95 & .476 & .243 & 9.1 & 29.3 \\
\hline
\end{tabular}

Sources: See Table 1 for employment statistics. Poverty figures are from U.S. Bureau of the Census 1993a, 1994, 1995a. 
a rather flat trend during the last half for both groups. Clearly, the employment and earnings of young people have some influence on the incomes of their families, and the racial differences in the earnings of young people can explain some part of the racial differences and trends in poverty. Although over the long span of U.S. history, gains in family income and reductions in poverty have been accompanied by decreased labor force participation rates of young people, this relation began to change around 1965, when the E/Ps of white youth stopped declining.

Table 2 also shows the average E/P's of 16-19-year-old males, black and white, for the same eight periods between 1959 and 1995. From 1961 to 1995 there is generally a negative relation between youth employment and family poverty for white families, which is largely attributable to cyclical effects. That is, during periods of relatively low unemployment, youth E/Ps were high and family poverty rates were low. The poverty trend is the same for blacks as whites, but only during the last 15 years, 1981-95, are black youth E/Ps and black family poverty rates negatively related.

We hasten to say that we do not view teenage employment as a major cause of the changes in the poverty rate of families or of the black-white differences in family poverty. Among blacks even the negative correlation between youth employment and family poverty is weak, aside from considering the causal linkage. The time-series statistics do indicate, however, that youth employment has served to widen the income and poverty gap between white and black families and, our next point, to widen the income gap between rich and poor families.

A Positive Relation between Parents' Income and the Employment of Their Teenage Children?

Several researchers have used cross-sectional data and have found a positive relation between work rates of young people and their parents' income (or family income not including the income of the 
young person). ${ }^{8}$ This relation holds despite the facts that (a) the theory of labor supply usually assumes that leisure is a normal good, which implies that higher parental incomes should lead, other things equal, to less time in market work by their children; ${ }^{9}$ (b) school enrollment among 16-19-year-olds is higher among high-income families; ${ }^{10}$ and (c) young persons who are enrolled in school are less likely to be employed. $^{11}$

Among white families the cross-section positive relation between parental income and work by their children (ages 16-19 and in residence) is also roughly consistent with the time-series relation from the mid-1960s to date. Parents' income and youth employment both increased from the mid-1960s until the mid-1970s, and the declines and slowdown in white youth employment since the mid-1970s have also accompanied declines and slowdown in parents' income. We are not arguing that the "pure" income effect on the labor supply of youth is positive, which would imply that leisure and/or time spent in school are inferior goods. An alternative explanation for the time-series relation is simply that for youth the positive effect on work of rising real wages dominates the negative income effect. Another explanation

${ }^{8}$ Bowen and Finegan (1969, p. 387), show a weak positive relation between parents' income and the labor force participation rate of their children in the 1-in-1,000 sample of the 1960 census, especially evident over the parents' income range from $\$ 3,000$ to $\$ 15,000$, which covered about 80 percent of all families in their data. See also Cain and Finnie (1990), based on data from the 1980 census, and Cain and Gleason (1991).

${ }^{9} \mathrm{Phrased}$ another way, children may be assumed to prefer leisure to work, other things equal, and children of richer parents have less need to work.

${ }^{10}$ Using special tabulations from the 1980 decennial census, Cain (1987, p. 27) reports that in April of 1980 approximately 80 percent of 17 -year-old white men in families with incomes under $\$ 20,000$ were enrolled in school, compared with 90 percent in families with incomes over \$20,000. Among 17-year-old black men, the corresponding enrollment rates were 85 percent and 90 percent. Earnings, if any, of the 17-year-old sons were excluded from the family incomes for these calculations to permit a measure of family income that was mostly unaffected by the schooling and employment status of the son. See also the strong negative relation between family incomes and high school dropout rates shown for 1991 in data from the National Center for Education Statistics (McMillen et al. 1993). Other issues of this annual series of NCES also provide evidence for this relation.

${ }^{11}$ Among 16-19-year-olds the negative relation between school enrollment and employment holds consistently only for males. See the November issues of Employment and Earnings, the labor force report of the U.S. Department of Labor. In 1991 the E/P for males ages 16-19 who were enrolled in school was 32.5; not enrolled, 67.3. For females the corresponding E/Ps were 36.2 and 33.1. Being married, bearing and raising children, and performing other household work are likely explanations for the low E/P for women ages 16-19 who are not enrolled in school. 
for the positive cross-section relation between a family's income and the probability of employment of their 16-19-year-old children is that the youth in higher-income families can obtain better jobs, perhaps because of their parents' "connections" in the labor market and because their parents live in more prosperous neighborhoods with better employment opportunities for young people. Finally, there may be unobserved personal traits that cause low productivity among members of poor families, such as a lower quality of education for a given number of years of schooling completed. Whatever the underlying causes, the positive relation between parental income and their teenage children's employment implies that youth employment is a force in widening family income inequality as well as in widening racial income inequality.

The remainder of this paper proceeds as follows. In Sections II and III we use data from the Survey of Income and Program Participation (SIPP, of the Bureau of the Census), to document the statistical relation between youth employment and family poverty for blacks and whites, first with tabulations and then with an econometric model. In Section IV we present the results of simulations designed to determine how poverty rates among black families would change under alternative assumptions about youth employment.

\section{USING SIPP TO DESCRIBE THE RELATION BETWEEN THE EMPLOYMENT OF YOUNG MEN AGES 16-19 AND FAMILY POVERTY}

SIPP is a nationally representative panel survey with information on individuals' labor supply, income, and participation in government transfer programs. Beginning with the 1984 panel, a cohort of persons and families are followed for up to thirty-two months, with interviews taking place every four months. We use the 1985 and 1986 panels, covering the period between late 1984 and early 1988 , to tabulate the relation between the employment of young men ages 16-19 living with their parents, and the poverty status of their families. Three family-income classifications are used: below the poverty line 
(poor), between 1 and 1.5 times the poverty line (near poor), and above 1.5 times the poverty line (nonpoor). Family income is measured over a twelve-month span. (We have also used samples of young men who were in the SIPP sample for as few as six months and three months to obtain larger sample sizes. The results based on these larger samples were similar to the results based on the twelve-month sample and are not presented here.)

As shown in Table 3, the incidence of poverty is high among black families with a teenage male and low among corresponding white families. Among the black families, 38 percent are poor, 18 percent near poor, and 44 percent are nonpoor. Among the white families, 6 percent are poor, 7 percent are near poor, and 87 percent are nonpoor.

At all income levels, employment proportions among 16-19-year-old black men are less than the employment proportions of 16-19-year-old white men (item 2 in Table 3). Overall, young black men are employed in only 26 percent of the months in a year, compared with 49 percent for young white men. ${ }^{12}$ The employment difference between the races is notably pronounced for poor families, where the months employed for blacks, 14 percent, is about half (.52) that for whites, 27 percent. Among nonpoor families the black-white ratio is $38 / 52=.73$. Clearly the relation between the employment levels for young men and their family incomes is sharply negative, especially so for blacks. (As we show in the next section, this negative relation remains when we exclude the earnings of the young men from their family incomes.) The large percentage of black families in poverty (38 percent compared to 6 percent for whites), combined with the low level of employment for the young black men who live in these families, presents a bleak picture, but one in which the potential economic gains from improvements in their employment have considerable scope.

\footnotetext{
${ }^{12}$ Differences in school enrollment do not explain this racial employment gap. The 16-19-year-old white men report being enrolled in school in 79 percent of the survey months, which is slightly more than for blacks-75 percent.
} 
TABLE 3

Employment and Earnings of Young Men Ages 16-19 and Their Family's

Poverty Status (1985-86 SIPP Data)

White

Black

B/W Ratio

1. Poverty status of families

(percentage distribution)

Poor $^{\mathrm{a}}$

Near poor

Nonpoor

\begin{tabular}{ccc}
$6 \%$ & $38 \%$ & 6.3 \\
7 & 18 & 2.6 \\
87 & $\underline{44}$ & 0.5 \\
\hline 100 & 100 &
\end{tabular}

2. Percentage of months per year

employed young men, ages 16-19

Poor

$27 \%$

$14 \%$

.52

Near poor

Nonpoor

52

38

.73

Total (all families)

49

.53

3. Average annual earnings of young

men (workers and nonworkers) ${ }^{\mathrm{b}}$

Poor

$\$ 1,322$

$\$ 717$

.54

Near poor

1,671

943

.56

Nonpoor

2,928

2,532

2,750

1,553

.86

Total (all families)

4. Hypothetical average annual

earnings of the young men

if worked 12 months $^{\mathrm{c}}$

Poor
Near poor
Nonpoor
Total (all families)

5. Number of families with a

resident young man age 16-19

for 12 consecutive months

$\begin{array}{rrr}\$ 4,897 & \$ 5,123 & 1.05 \\ 4,777 & 4,716 & .99 \\ 6,504 & 6,664 & 1.02 \\ 5,614 & 5,974 & 1.06\end{array}$

Source: Special tabulations from the 1985 and 1986 SIPP.

a"Poor" refers to young men whose family income is below the poverty line; "near-poor" to between 1 and 1.5 times the poverty line; "nonpoor" to above 1.5 times the poverty line.

${ }^{b}$ To obtain the value of the dollar amounts in this table in 1996 dollars, multiply by 1.4 , which is the inflation factor from 1986 to 1996.

${ }^{\mathrm{c}}$ The hypothetical full-year earnings are calculated by dividing each earnings amount in item 3 by the decimal form of the percentages of months employed in item 2, cell by corresponding cell. See the discussion in the text concerning why these hypothetical annual earnings probably overstate the $\mathrm{B} / \mathrm{W}$ ratio if all young men worked 12 months. 
The black/white ratios of earnings among 16-19-year-old men (item 3) are similar to their employment ratios (item 2), which implies that the labor market disadvantage of black youth is almost entirely a result of their lower employment levels. (Note that the earnings amounts in item 3 would be higher in 1996 by a factor of 1.4 to allow for the rise in the Consumer Price Index from 1986 to 1996.) Indeed, as shown in item 4 , the hypothetical average annual earnings obtained if the young men all worked twelve months would roughly equalize the earnings of black and white youth. The hypothetical full-year black-to-white earnings ratios in item 4 are, however, probably upwardly biased relative to what the ratios would be if the same proportion of blacks and whites were actually employed. Such a bias would exist if, as seems reasonable, the young men who are employed are selected from the higher end of the distribution of wage-earning abilities. Since the proportion of young black men who are employed is much smaller than the proportion of white men employed, the employed blacks represent the higher end of the wage distribution to a greater extent than is the case for whites.

\section{INSIGHTS FROM ESTIMATING THE DETERMINANTS OF THE EMPLOYMENT OF YOUNG MALES}

The 1985 and 1986 panels of SIPP are used to estimate the probability of employment in a given month for 16-19-year-old black and white men as a function of available personal, family, and labor market characteristics. ${ }^{13}$ Our interest in the labor market of residence required us to restrict our sample to households living in standard metropolitan statistical areas (SMSAs) to measure such variables as the area's unemployment rate and its industrial structure. In 1990, 80 percent of the U.S. population lived in SMSAs. The panel survey was carried out for thirty-two months, so there are up to thirty-two monthly observations for each person. The dependent variable in our probit estimation model is a binary variable,

\footnotetext{
${ }^{13}$ The labor market variables were appended to the original SIPP data set, using the County and City Data Book, 1988 of the U.S. Bureau of the Census. Access to the city and county residence of the SIPP respondents is available to Census Bureau employees and was available to us during our period of research at the Census Bureau.
} 
one if working in the month, zero otherwise. Table 4 shows the independent variables used in the probit estimates, along with their means (in parentheses) and the estimated "effects" of the change in employment probability with respect to a specified (usually a unit) change in the independent variable, evaluated at mean levels for the other independent variables. We use quotes around the term effects, because the term's implication that the coefficients measure causal impacts of changes in the right-handside variables is not always warranted, as we will discuss.

Because we focus on the relation between youth employment and poverty, we limit our discussion of Table 4 to personal and market variables that have a relatively direct relation to poverty status. Other variables, such as age, having a health limitation on working, and Hispanic ethnicity, serve mainly descriptive purposes or as "control" variables. ${ }^{14}$

For both black and white men ages $16-19$, the probability of employment is positively related to their family's income (excluding their own income), and the relation is stronger for black youth. Our estimates show that an increase of $\$ 500$ in monthly income for white families has a small positive (.002) and statistically insignificant effect on the employment probability of young white men. ${ }^{15}$ This implies a response elasticity of only .03. An increase of $\$ 500$ in monthly income for black families, however, is predicted to increase the employment probability of 16-19-year-olds by .018, an elasticity of .23. Note

\footnotetext{
${ }^{14}$ For a more complete discussion of these estimations, as well as the results of a variety of other models of employment and earnings among white and black men, ages 16-19 and 20-24, see Cain and Gleason (1991). We note here that one unexpected coefficient in the estimates for blacks is .16 for the binary variable indicating the presence of a heath limitation. The coefficient is not statistically significant, and we have no explanation for its unexpected sign.

${ }^{15}$ Statistical significance of the probit estimates in Table 4 is indicated to an approximation by the asterisks alongside the coefficients. Because we use person-months as units of observation there is a person-specific source of non-independence among the observations. In addition there is possible serial correlation, even though we control for the calendar year and whether the month was a summer month. Finally, SIPP's sample design is geographically clustered. To allow for the overstatement of statistical significance that results from these sources of nonindependence of our observations, we have applied a rule-of-thumb deflation factor to our reported t-ratios that we obtained from trial estimations of regression models that used a variance correction procedure developed by Robert Fay, of the U.S. Bureau of the Census. We are indebted to Fay for his calculations for us of corrected standard errors, using his CPLX software program that incorporates a jackknife procedure for computing the standard errors of estimated coefficients.
} 
TABLE 4

Estimated Marginal Effects of Independent Variables on the Probability of Employment in a Given Month among Men 16-19, 1985 SIPP Data

\begin{tabular}{|c|c|c|c|c|}
\hline \multirow[b]{2}{*}{ Independent Variable } & \multicolumn{2}{|c|}{ White } & \multicolumn{2}{|l|}{ Black } \\
\hline & Marginal Effect & (Mean) & Marginal Effect & (Mean) \\
\hline Monthly family income ${ }^{a}$ & .00 & $(\$ 3,313)$ & $.02 * * *$ & $(\$ 1,901)$ \\
\hline Hispanic & $.11 * * *$ & $(.11)$ & $-.20 * *$ & $(.04)$ \\
\hline Year: 1984 & .00 & $(.05)$ & .04 & $(.06)$ \\
\hline 1986 & .00 & $(.36)$ & -.00 & $(.34)$ \\
\hline 1987 & -.03 & $(.17)$ & .02 & $(.15)$ \\
\hline Summer month & $.13 * * *$ & $(.20)$ & .05 & $(.20)$ \\
\hline Age: $\quad 17$ & $.20 * * *$ & $(.26)$ & $.26 * * *$ & $(.27)$ \\
\hline 18 & $.25 * * *$ & $(.25)$ & $.33 * * *$ & $(.25)$ \\
\hline 19 & $.33 * * *$ & $(.25)$ & $.36 * * *$ & $(.24)$ \\
\hline Parents on welfare & $-.07 * *$ & $(.10)$ & -.03 & $(.29)$ \\
\hline Health limitation & $-.07 *$ & (.04) & .16 & $(.04)$ \\
\hline Education: lagging behind ${ }^{\mathrm{b}}$ & $-.17 * * *$ & (.19) & $-.35 * * *$ & $(.29)$ \\
\hline on $\operatorname{track}^{\mathrm{b}}$ & -.05 & $(.46)$ & $-.23 * * *$ & $(.48)$ \\
\hline some college ${ }^{b}$ & $-.10 * * *$ & $(.24)$ & $-.24 * * *$ & $(.12)$ \\
\hline Enrolled in school & $-.17 * * *$ & $(.75)$ & -.10 & $(.72)$ \\
\hline Proxy response ${ }^{c}$ & $-.10 * * *$ & $(.74)$ & $-.16^{* * *}$ & $(.74)$ \\
\hline Living alone $\mathrm{d}^{\mathrm{d}}$ & .03 & $(.08)$ & -.01 & $(.15)$ \\
\hline One parent ${ }^{\mathrm{d}}$ & -.03 & $(.22)$ & -.02 & $(.50)$ \\
\hline Nonlabor income $^{\mathrm{e}}$ & $-.12 * * *$ & $(.04)$ & -.08 & $(.01)$ \\
\hline Subsidized-rent housing & .05 & $(.01)$ & .05 & $(.03)$ \\
\hline Public housing & .00 & $(.02)$ & $-.10^{*}$ & (.13) \\
\hline Central city residence & -.05 & $(.35)$ & .00 & $(.53)$ \\
\hline Segregation index & .01 & $(2.74)$ & .01 & $(2.59)$ \\
\hline Log population ${ }^{\mathrm{f}}$ & $.01 * * *$ & $(2.6 \mathrm{M})$ & .00 & $(3.2 \mathrm{M})$ \\
\hline Percentage black & -.00 & $(16)$ & $-.01 * * *$ & $(22)$ \\
\hline 1986 unemployment rate & .00 & $(6.5)$ & $-.02 * *$ & $(7.0)$ \\
\hline 1982 log per capita retail sales ${ }^{\mathrm{g}}$ & .01 & $(\$ 4,720)$ & $-.05 * * *$ & $(\$ 4,545)$ \\
\hline Number (person-months) & & 10,871 & 2,08 & \\
\hline Employment-to-population ratio & & .53 & .31 & \\
\hline
\end{tabular}

Source: 1985 SIPP panel.

Note: The term "effect"int he headings of columns 2 and 4 does not necessarily imply a causal effect.

See the text discussion of this point.

${ }^{a}$ Family income excludes the earnings of the 16-19-year-old male. Its estimated marginal effect refers to a response to a $\$ 500$ increase in monthly income.

${ }^{\mathrm{b}}$ The excluded education variable indicates the receipt of a high school degree only.

${ }^{c}$ Respondent is someone other than the 16-19-year-old male.

"Living with two parents is the excluded variable. "Living alone" indicates living away from parents.

${ }^{e}$ Nonlabor income is a dummy variable: 1 if family received $\$ 100$ or more of (mainly) rent, interest, dividend, or capital gains in the month; zero otherwise.

${ }^{\mathrm{f}}$ The estimated marginal effect refers to a response to an increase of one million in population.

${ }^{\text {g}}$ The estimated marginal change refers to an increase of $\$ 750$ in per capita retail sales. 
that the mean income of black families ( $\$ 1,901$ per month in 1986 dollars) is much lower than that of white families $(\$ 3,313)$, so black youth would be predicted to have a lower employment rate even if their response elasticity were the same. As discussed above, a causal explanation for this positive incomeemployment relation is not well understood. Thus, the policy implications of this relation are unclear.

The indicator (or dummy) variable of nonlabor income represents a family that receives $\$ 100$ or more per month of (mainly) property income, such as rents, dividends, interest payments, and capital gains. Transfer payments are not included. Only 4 percent of white families and 1 percent of black families are included in this category of income recipients. The distribution of property income is highly skewed and tends to be concentrated in the possession of wealthy people. Thus, the large negative effects of this variable on the probability of the employment of the young person applies to less than 5 percent of the households.

Four other independent variables are connected to family income: living in a one-parent family, living in a family that receives government cash transfer payments (mainly AFDC payments), living in public housing, and living in rent-subsidized housing. Each variable may be viewed, in part, as an indicator of low permanent (or normal) income, given that current income is observed and controlled for in the estimation model. In part, each variable also represents its own particular influences on labor supply; for example, lack of a male role model for children in families with only a mother present, poor neighborhoods where public housing is prevalent, and so on.

Fully 50 percent of the black youth live in a one-parent household, compared to 22 percent of the whites, but the negative influence of this variable on the probability of employment is small and statistically insignificant for both white and black youth: -.03 and -.02 respectively. Welfare status, by itself, has a relatively large negative relation to youth employment for whites, -..10, which implies that a white 16- to 19-year-old man who lives in a family that is receiving welfare benefits has a 10 percent lower probability of being employed than a comparable white whose family is not on welfare. This is a 
sizable implied effect, but only 10 percent of white families reported receiving welfare payments. The welfare coefficient for blacks is small, -..03, but 29 percent of the black families report receiving welfare payments. ${ }^{16}$ Living in public housing has a statistically significant and large negative effect on the employment probability of black youth, -.10, and 13 percent of black families live in public housing. The effect is zero for whites. The percentage of both black and white families who live in rent-subsidized housing is very small, and the variable has no effect. While the separate effects of the four povertyrelated variables are small, their cumulative negative effect on the youth's employment probability may be sizable, given that each of the three statuses (ignoring living in rent-subsidized housing)—-living with a single parent, in public housing, and being on welfare—are positively correlated with the other two.

Two personal variables that must be interpreted with particular care, because they are arguably endogenous to the employment process, are school enrollment and school attainment. ${ }^{17}$ School attainment is specified by four categorical variables: (1) being a nonenrolled high school graduate without any college experience (the omitted variable); (2) having some college experience; (3) having less than twelve years of schooling completed, but being "on track," in the sense that the number of years of schooling is standard for the person's age; and (4) "lagging behind," defined as having completed a number of years of schooling less than that which is standard for the person's age. This category would include high school dropouts. Enrollment status is controlled for by a separate variable.

\footnotetext{
${ }^{16}$ Being "on welfare" carries a high implicit tax on the earnings of the head of the household, usually the mother in a one-parent family. (The term "tax" is used because welfare payments are usually reduced as earnings increase.) However, this tax is generally not imposed on working children in these families. See Lerman (1986, especially p. 412). Lerman does find a large negative effect of living in a welfare family on the probability that the young person is employed, despite the exemption of the young person's earnings from the welfare tax. It could be argued that the income effect of welfare benefits discourages young people from working, but two points argue against this hypothesis: (a) welfare families have very low incomes, and (b) the observed relation between parental income and youth employment is positive in the general population.

${ }^{17}$ Living alone is another variable that is arguably endogenous to the employment process. However, only 8 percent of the 16-19-year-old white men and 15 percent of the 16-19-year-old black men live alone, and this variable is insignificantly related to employment for each group.
} 
School enrollment is, as expected, negatively related to employment, but it is presumably positively related to future earnings. Its negative effect is somewhat larger for whites than for blacks. School attainment is, also as expected, positively related to employment success, with a coefficient that is larger for blacks than for whites. Being either a high school dropout or, if in school, lagging behind has a large negative coefficient with respect to being employed, -.35 for blacks and -.17 for whites. These values represent the largest changes in probabilities of employment of any potentially policy-related variable in the model. Moreover, fully 29 percent of black youth are in this category, compared to 19 percent of the whites. Of course, we cannot determine what component of this schooling "effect" is exogenous and indicative of a response to a policy change and what component is merely reflective of unobserved personal traits.

Of clearer policy significance are the results for two variables that measure demand factors in the SMSA labor market where the young person lives. We assume that the young man's location, his SMSA of residence, is exogenous, which seems reasonable for 16- to 19-year-olds, almost all living with their parents. In particular, we assume that two variables, the 1986 unemployment rate and the 1982 level of per capita retail sales, are exogenous to the young person's employment status. We choose retail sales as a proxy for demand because this industry is the largest provider of jobs for teenagers. The effects of these variables on the probability of employment of white 16-19-year-olds are negligible, but for black youth the variables have the expected sign, are relatively large, and are statistically significant. ${ }^{18}$

Other SMSA characteristics have a small impact on youth employment. Among young black men, living in an SMSA where a large fraction of the population is black has a negative effect on employment. The effect of this variable on the employment of 16-19-year-old white men is insignificant.

\footnotetext{
${ }^{18}$ In estimations (not shown) of this model for young men ages 20-24, the effect of unemployment is significantly negative for both whites and blacks, and the effect of retail sales is positive but insignificant for whites and positive and marginally significant for blacks.
} 
The effects of living in the central city (as distinct from the suburbs of the central city) and of an index of segregation in an SMSA are also insignificant for both white and black youth. ${ }^{19}$

In summary, the estimation results indicate that a number of factors are associated with, and arguably causal to, low employment of black youth: high levels of unemployment in the area where the youth lives, low levels of teenage job availability, low educational attainment, low family income, and the combined negative effects on youth employment of three poverty-related variables-one-parent families, the receipt of welfare payments, and living in public housing. These results suggest a role for policy intervention to increase the employment opportunities of black youth and to improve the general income and living standards of black families. The next section examines the quantitative effect on family poverty from changes in youth employment.

\section{SIMULATIONS OF THE INCIDENCE OF POVERTY}

Tables 5 and 6 show the results of several types of simulation that were conducted to measure the change in the incidence of poverty that might occur if youth employment and earnings were changed in specified ways. Table 5 shows the change in poverty if the current earnings of the 16-19-year-old males were excluded from current family incomes, on the assumption that no other changes in family incomes or in family composition would occur. The poverty rate rises, and we see that the increase is relatively larger among white families. This is not surprising, because a larger proportion of white youth are employed than black youth. The number of poor black families increases by 8 percent (from 95 to 103),

\footnotetext{
${ }^{19}$ In a specification not shown here, however, the coefficients on central city residence and on the segregation index are both positive, and the coefficient on an interaction between them is negative and significant for black youth. This implies that in highly segregated cities, living in the central city has a negative influence on a black youth's chances of working. In cities that are less segregated, however, living in a central city is beneficial to a black youth's employment probability.
} 
TABLE 5

Number of Families That Are Poor, Near Poor, and Nonpoor When Excluding or Including the Earnings of Young Men Ages 16-19, 1985-1986 SIPP Data

A. Number of families in the sample with a resident male age 16-19 for twelve consecutive months, under specified income conditions

\begin{tabular}{|c|c|c|c|c|c|c|}
\hline \multirow[b]{3}{*}{ Family Income $^{a}$} & \multicolumn{6}{|c|}{ Youth Earnings } \\
\hline & \multicolumn{3}{|c|}{ White $(\mathrm{n}=1,678)$} & \multicolumn{3}{|c|}{ Black $(n=248)$} \\
\hline & Incl. & Excl. & \%Chng. & Incl. & Excl. & \%Chng \\
\hline Poor & 105 & 145 & $38 \%$ & 95 & 103 & $8 \%$ \\
\hline Near poor & 118 & 150 & 27 & 45 & 45 & 0 \\
\hline Nonpoor & 1,455 & 1,383 & -5 & 108 & 100 & -7 \\
\hline Poverty rate & .063 & .086 & 37 & .383 & .415 & 8 \\
\hline
\end{tabular}

B. Number of families in the sample with a resident male age 16-19 for three consecutive months, under specified income conditions

Youth Earnings

\begin{tabular}{|c|c|c|c|c|c|c|}
\hline \multirow[b]{2}{*}{ Family Income } & \multicolumn{3}{|c|}{ White $(\mathrm{n}=2,335)$} & \multicolumn{3}{|c|}{ Black $(n=332)$} \\
\hline & Incl. & Excl. & \%Chng. & Incl. & Excl. & $\%$ Chng. \\
\hline Poor & 178 & 252 & $42 \%$ & 122 & 134 & $10 \%$ \\
\hline Near poor & 173 & 207 & 20 & 60 & 60 & 0 \\
\hline Nonpoor & 1,984 & 1,876 & -5 & 150 & 138 & -8 \\
\hline Poverty rate & .076 & .108 & 42 & .367 & .404 & 10 \\
\hline
\end{tabular}

Source: Special tabulations from the 1985 and 1986 SIPP.

a“"Incl." refers to family income that includes the earnings (if any) of the 16-19-year-old. "Excl." refers to family income that excludes the earnings (if any) of the 16-19-year-old, and assumes no other change in family income.

${ }^{\mathrm{b}}$ In panel B the three-month earnings data are annualized. 
the number of the near poor does not change, and the number of nonpoor decreases by 7 percent (from 108 to 100). Thus, the incidence of poverty increases from .38 to .42 .

Among white families, excluding the earnings of 16-19-year-old males leads to an increase of 38 percent in the number of poor families (from 105 to 150), an increase of 27 percent in the number of near-poor families (from 118 to 145), and a decrease of 5 percent in the number of nonpoor families (from 1,455 to 1,383). The incidence of poverty increases from .06 to .09.

Also shown in Table 5 are the results of excluding the earnings of young men ages 16-19 on the proportions in the three income groups based on a sample in which we have at least three consecutive months of a 16-19-year-old male living in the family. Our main purpose is to obtain a larger sample size, especially for blacks, but the incidence of poverty based on a three-month accounting period (with the income adjusted to annualize it) is of interest on its own. These samples, larger by 34 to 40 percent, show results similar to those based on twelve months of data.

In Table 6 nine simulated changes in the earnings of black young men ages 16-19 are carried out to measure the resulting change in the poverty rate and in the average poverty gap, defined as the average of each poor family's income minus the family's poverty line. Again, we assume that increases in a young man's employment and earnings do not change his living arrangements or the earnings of his parents. The simulated changes in the numbers and proportions in the near-poor and nonpoor groups do not show any unexpected results and are not shown in the table.

Simulations 1 and 2, hereafter S1 and S2, show the changes in the poverty rate and the poverty gap if all black youth earned the mean earnings of all white youth (S1) and all nonpoor black youth (S2). The mean earnings of these assignments are shown in column (2), and for these two simulations the means are calculated with observations for both workers and those who did not work. S1 and S2 are based on changes that ought to be feasible policy goals. The impact on the poverty rate is modest, dropping to .34 from the base level of .38 in both cases. The reduction in the poverty gap is more 
TABLE 6

Simulated Poverty Rates for Black Families under Different Assumptions about Earnings of Black Males Ages 16-19, (1985-86 SIPP Data)

Simulation $^{\mathrm{a}}$

BASE: Poverty rates with actual earnings averaged over all black youth

S1. All black youth earn mean earnings of whites

S2. All black youth earn mean earnings of nonpoor black youth

S3. All black workers earn mean earnings of white workers

S4. All black workers earn mean earnings of nonpoor black workers

S5. All black youth earn mean earnings of white workers

S6. All black youth earn mean earnings of nonpoor black workers

S7. Black youth are randomly chosen to equal the employment percentage of white youth and earn the white workers' mean earnings

S8. Black youth randomly chosen to equal the employment percentage of white poor*, near poor\#, nonpoor@(32\%, 42\%, 53\%) and earn the whites' mean earnings ${ }^{\text {b }}$

S9. Employment percentage and earnings of black youth are determined as if their characteristics are rewarded the same as white characteristics ${ }^{\mathrm{c}}$
Mean Monthly

Earnings Used (\$)

$\$ 130$

.383

$-5,586$

Source: Special tabulations of the 1985 and 1986 SIPP.

aThe simulation is based on a sample size of 248 black families.

b"Poor" refers to young men whose family income is below the poverty line; "near poor" to between 1 and 1.5 times the poverty line; "nonpoor" to above 1.5 times the poverty line. The percentages 32 , 42, and 53 are those of white youth in poor, near poor, and nonpoor families, respectively.

${ }^{\mathrm{c}}$ The employment status of black youth is determined by multiplying the values of their characteristics (age, etc.) by the coefficients of these characteristics from the employment probit model for white youth shown in Table 4. The earnings of black youth are determined analogously; that is, by multiplying the values of their characteristics by the coefficients from a regression for white youth with earnings as the dependent variable (regression not shown, see Cain and Gleason 1991). These simulations were conducted using only the 1985 SIPP panel. In the same type of simulation but with the estimated coefficients for black youth as well as the values of the characteristics of black youth, the resulting poverty rate is .346 and the poverty gap is $-\$ 6,451$. See text for further discussion of these simulations. 
impressive: the average poor family's gap is reduced in $\mathrm{S} 1$ from $\$ 5,586$ to $\$ 3,975$, a 29 percent reduction, and reduced in S2 by 25 percent. Interestingly, the reduction achieved by assigning to all black youth the monthly earnings of black youth $(\$ 211)$ in nonpoor families is about the same as the reduction from an assignment of the monthly earnings (\$231) of white youth. We will refer to the S2 type of change as a poor/nonpoor difference, and to $\mathrm{S} 1$ as a black/white difference.

The next pair of simulations, S3 and S4, which assign to the young black workers the mean earnings of white workers in S3 or the mean earnings of nonpoor black workers in S4, have virtually no effect on the poverty rate or gap relative to the base levels. The reason is that among 16-19-year-old men nearly the entire source of lower earnings of blacks relative to whites stems from the lower employment levels of the blacks, and not from lower earnings among those who have jobs.

Simulations S5 and S6 illustrate a particular version of an upper bound on the effect of increased earnings on poverty. The black youth are assumed to have a 100 percent employment rate and to earn the mean earnings of white 16-19-year-old workers in S5 and to earn the higher mean earnings of the nonpoor black 16-19-year-old workers in S6. The black poverty rate is virtually halved, but the rate is still almost three times that of whites, even though the simulation assumption is unrealistically beneficial to blacks.

Simulations S7 and S8 are two different ways of allowing black youth employment and earnings to match those of white youth. In S7 a randomly chosen group of blacks is assumed to be employed and each worker is assigned the mean earnings of white workers. The random selection is done in such a way that the black youth employment proportion matches that of white youth. The poverty rate resulting from this simulation declines from .38 , the base rate, to .32 , which is slightly lower than in $\mathrm{S} 1$. Note that this simulation removes not only the differences in employment and earnings between blacks and whites but also the poor/nonpoor differences. Simulation S8 repeats the same random selection process so that the black employment percentage and mean earnings are matched to the white employment percentage and 
mean earnings in each of the three income strata. Thus, this simulation does not remove the differences in poor/nonpoor employment and earnings. It yields only a small reduction in black poverty, from .38 to .37 . The reason is that even though the employment proportion of the 16-19-year-olds in poor white families is about twice as high as among blacks, 27 percent compared to 14 percent, it is much lower than the employment proportion of 49 percent among all white youth, which was used in S7.

In the final simulation shown in Table 6 we assumed that the characteristics used in the estimation models for employment and earnings are rewarded in the labor market equally for blacks and whites; specifically, the white coefficients ("effects") of the characteristics are assigned to the black values of the characteristics. The employment model is shown in Table 4. The earnings models are not shown, but the list of characteristics is the same. (The estimations are based on the 1985 SIPP panel.) We find that the incidence of poverty among blacks is reduced from .35 to .31 , an 11 percent reduction, and that the poverty gap is reduced from $\$ 6,451$ to $\$ 5,155$, a 20 percent reduction. ${ }^{20}$ Thus, simply having a labor market that provides young black males the same effects on employment and earnings as those estimated for white males would lead to a substantial decrease in poverty.

In summary, we refer to simulations 1 and 2. Simulation 1 assigned increases in the earnings of 16-19-year-old black men up to the levels of 16-19-year-old white men, and this yielded a modest reduction of 12 percent in the black poverty rate and a substantial reduction of 29 percent in the poverty gap, which is a more comprehensive measure of an impact on poverty. Simulation 2, which assigned the average earnings of nonpoor black men ages 16-19 to poor black men ages 16-19 brought about a similar reduction in poverty, which shows that the lag in employment by black youth in poor families behind that

\footnotetext{
${ }^{20}$ Note that the base poverty rate and poverty gap used in S9 differ from those in the top row of Table 6 for two reasons. First, S9 is based on data from the 1985 SIPP panel, but the remainder of Table 6 uses both the 1985 and 1986 panels. Second, the base figures for S9 are calculated by using black characteristics and black coefficients to predict youth earnings - and then adding predicted youth earnings to family income to determine whether the family is above or below the poverty line. By so doing we make these base figures analogous to the S9 figures, and we can attribute any differences to the differences between the white and black coefficients, rather than to the methodology used to predict youth earnings.
} 
of black youth in the relatively well-off families is another source of the high incidence of poverty in black families. A somber point is that the lag in youth employment of blacks relative to whites has been very large in recent years. As mentioned previously, it is employment, rather than the earnings of those employed, that is the main source of the black disadvantage in the youth labor market.

\section{CONCLUSIONS}

This paper investigates the relation between youth employment and the poverty status of their families. This is a relatively narrow part of the larger and vexing problem of the white-black gap in youth employment performance. Most research has dealt with the latter problem because of the concern with the long-run prospects for economic equality between whites and blacks. The direct focus of this paper is on the immediate influence of youth employment on family income and on current black-white differences in the incidence of poverty.

We have found that improving the employment proportions among black young men ages 16-19 can reduce the amount of poverty in their families to a moderate, but meaningful, degree. Moreover, policies that improve the labor market opportunities of black youth would have larger effects than our calculations show, because the employment among young black women ages 16-19 and among 20-24-year-olds of both sexes would also increase. This paper has not taken account of the employment of these groups.

We also suggest that a small feedback relation between black youth employment and family income exists that would serve to magnify gains if either variable were increased. We doubt that parents would decrease their earnings if their children earned more, and higher family incomes might lead to residential moves to better neighborhoods and a local environment that offers more employment opportunities. Less speculative are the findings of the negative effects on youth employment of several variables that are also associated with poverty, such as marketwide unemployment, one-parent families, 
and low educational attainment. Improvements in these conditions would raise both youth employment and their family incomes. 



\section{References}

Bowen, William G., and T. Aldrich Finegan. 1969. The Economics of Labor Force Participation. Princeton: Princeton University Press.

Cain, Glen G. 1987. "Black-White Differences in Employment of Young People: An Analysis of 1980 Census Data." Institute for Research on Poverty, Discussion Paper No. 844-87, University of Wisconsin-Madison.

Cain, Glen G., and Ross E. Finnie. 1990. "The Black-White Difference in Youth Employment: Evidence for Demand-Side Factors." Journal of Labor Economics 8(1, pt. 2): S364-S395.

Cain, Glen G., and Philip M. Gleason. 1991. "Using SIPP to Analyze Black-White Differences in Youth Employment." Proceedings of the 1991 Annual Research Conference. Washington, D.C.: U.S. Bureau of the Census.

Lerman, Robert. 1986. "Do Welfare Programs Affect Schooling and Work Patterns of Young Black Men?" In The Black Youth Unemployment Crisis, ed. Richard B. Freeman and Harry J. Holzer, pp. 412-441. Chicago: University of Chicago Press.

McMillen, M. M., P. Kaufman, E. G. Hausken, and D. Brady. 1993. Dropout Rates in the United States, 1992. Washington, D.C.: National Center for Education Statistics, Report No. 93-464.

Moss, Philip, and Chris Tilly. 1991. Why Black Men Are Doing Worse in the Labor Market: A Review of Supply-Side and Demand-Side Explanations. New York: Social Science Research Council.

U.S. Bureau of the Census. 1943. 1940 Census of the Population, Vol. II: Characteristics of the Population, Part 1, U.S. Summary. Washington, D.C.

U.S. Bureau of the Census. 1961. Current Population Reports. Series P-20. "Marriage, Fertility, and Childspacing." No. 108. Washington, D.C.

U.S. Bureau of the Census. 1964. 1960 Census of the Population: U.S. Summary, Vol. 1, Part 1, Sec. D. Washington, D.C.

U.S. Bureau of the Census. 1983. 1980 Census of the Population: General Population Characteristics: U.S. Summary, PC80-1-B1. Washington, D.C.

U.S. Bureau of the Census. 1989. County and City Data Book, 1988. Washington, D.C.

U.S. Bureau of the Census. 1992. Current Population Reports. Series P-20. "School Enrollment and Social and Economic Characteristics of Students.” No. 460. Washington, D.C.

U.S. Bureau of the Census. 1993a. Current Population Reports. Series P-60. "Poverty in the United States: 1992.” No. 185. Washington, D.C.

U.S. Bureau of the Census. 1993b. Current Population Reports. Series P-20. "Fertility of American Women, June 1992.” No. 470. Washington, D.C. 
U.S. Bureau of the Census. 1994. Current Population Reports. Series P-60. "Income, Poverty, and Valuation of Noncash Benefits.” No. 189. Washington, D.C.

U.S. Bureau of the Census. 1995a. Current Population Reports. Series P-60. "Poverty in the United States." No. 194. Washington, D.C.

U.S. Bureau of the Census. 1995b. Statistical Brief 95-2. "Mothers Who Receive AFDC Payments: Fertility and Socioeconomic Characteristics." Washington, D.C.

U.S. Bureau of the Census. 1996. Current Population Reports. Series P-20. "School Enrollment and Social and Economic Characteristics of the Students.” No. 487. Washington, D.C.

U.S. Department of Labor. Bureau of Labor Statistics. Employment and Earnings. January issues, 1990-1996.

U.S. Department of Labor. Bureau of Labor Statistics. 1989. Handbook of Labor Statistics. Bulletin 2340.

Welch, Finis. 1990. “The Employment of Black Men.” Journal of Labor Economics 8(1, pt. 2): S26-S74. 